\title{
Efficiency of Moderately Halophilic Bacillus spp. Isolated From Hypersaline Environments In Producing Levansucrase
}

\author{
1Adnan H. Abbas, 1Eman H. Abed, 2Seham M. Mohammed \\ ${ }_{1}$ Pollution Treatment Centre, Environment and Water Directorate, Ministry of Science and Technology, Baghdad, Iraq. \\ 2Ministry of Education, Baghdad, Iraq.
}

Corresponding author: Adnan H. Abbas, Pollution Treatment Centre, Environment and Water Directorate, Ministry of Science and Technology, Baghdad, Iraq.

E-mail: adn927an@gmail.com

Received date: 22 December 2017, Accepted date: 22 January 2018, Online date: 5 February 2018

Copyright: (C) 2018 Kareem Jaffer Alwan.This is an open-access article distributed under the terms of the Creative Commons Attribution License, whichpermits unrestricted use, distribution, and reproduction in any medium, provided the original author and source are credited.

\begin{abstract}
Background: Moderately halophilic bacterial strains were isolated and identified four species belong toBacillusspp. fromhypersaline environments (Sawa Lake), then determined their tolerating on nutrient agar supplemented with variousconcentrations of $\mathrm{NaCl}$ and sucrose ranges $(10-200) \mathrm{gm} / \mathrm{l}$ and ability to produce a slimy mucus when grown in tryptonesucrose agar medium with sucrose $(20 \mathrm{gm} / \mathrm{l})$, as carbon source. Results showed that Bacillus isolates were grown in concentrations of $\mathrm{NaCl}$ and sucrose up to $140 \mathrm{gm} / \mathrm{l}$ and $200 \mathrm{gm} / \mathrm{l}$, respectively. Biomass value for (Saw 2) isolate wasincreased gradually during a fermentation media supplemented with mixture of $(\mathrm{NaCl}+\mathrm{Sucrose})(10-100) \mathrm{gm} / \mathrm{l}$, after incubated for $48 \mathrm{~h}$ at $30^{\circ} \mathrm{C}$ and produced levansucrase at concentrations $(1-10) \mathrm{gm} / 100 \mathrm{ml}$ of $(\mathrm{NaCl}+$ Sucrose) with activity $(462.08,463.33$, $460.83,460.83,455.41,453.75,452.97,454.58,454.16$ and 452.07$) \mathrm{U} / \mathrm{ml}$ and descending in quantity of enzyme activity (439.37, 450.41, 431.66, 422.29, 381.04, 361.87, 312.29, 315, 276.25 and 251.87)U/ml when added sucrose to fermentation media more than $4 \mathrm{gm} / 100 \mathrm{ml}$.
\end{abstract}

Key words: Halophilic bacteria, Osmophilic bacteria, Levansucrase production.

\section{INTRODUCTION}

Moderately halophilic species of bacteria belong to Bacillaceae and Micrococcaceae, such as Paracoccus halodenitrificans and Micrococcus spp. involved in a wide diversity of natural habitats and flourish best in media containing (3-15)\% (W/V) NaCl (Kushner and Kamekura, 1988). They produce salt stable enzymes due to their ability to carry out catalysis under high salinity (Karan et al., 2012).

There are different strategies utilized by halophilic microorganisms to adjust their cytoplasm osmotically with their medium, includes aggregation of the molar concentrations of salts, similar to potassium and chloride, which requires broad adjustment of the intracellular enzymatic apparatus, as the proteins should maintain their structure and activity at high concentrations of salt (Lanyi, 1974).

Water availability [Water activity $\left(\mathrm{a}_{\mathrm{w}}\right)$ ] resolves both the vitality and practically of living systems. The most of microbes cannot multiply below $0.900 \mathrm{a}_{\mathrm{w}}$ (Manzoni et al., 2012; Moyano et al., 2013).

Whereas microorganisms, which can grow in high concentrations of organic solute, especially sugars, have been called osmophiles, because these organisms do not have an essential demand for reduced $\left(\mathrm{a}_{\mathrm{w}}\right)$ or high osmotic pressure, rather they tolerate drier environments better than non osmotolerant species (Stecchini and Beuchat, 1985).

Levansucrase ( $\beta$-2, 6-fructan: D-glucose-1- fructosyl transferase, E.C.2.4.1.10) are involved in the synthesis of fructan polymers known as Levan (Fructooligosaccharides). Levan has potential in the pharmaceutical and food industries (Esawy et al., 2013; Ruhmann et al., 2015). Several applications of levan are as follows: as an agent to increase the viscosity, stabilizer, emulsifier and water-binding to determine and modify the structure of food (Belghith et al., 2012). In pharmaceutical industries, levan is used as a drug carrier agent, anti-hyperglycemia, anti-diabetics (Ahmad et al., 2015), anti-tumor (Dahech et al., 2012), antivirus (Srikanth et al., 2015) and anti-oxidants (Dahech et al., 2013). In the environmental field, levan can be used as bio-sorbent and bio-flocculants (Sogotcu etal., 2012).

The research goal to study the efficiency of moderately halophilic bacteria isolated from Sawa Lake in the production of levansucrase.

\section{MATERIALS AND METHODS}

Isolation of Bacillus isolates:

The sample of Sawa Lake was heat-treated $\left(80^{\circ} \mathrm{C}\right.$ for $\left.10 \mathrm{~min}\right)$ and individually subcultures on nutrient agar plates, then incubated for $24 \mathrm{~h}$ at $30^{\circ} \mathrm{C}$ and colonies were recovered and purified by streaking on fresh nutrient agar.

Screening of moderately halophilic Bacillus isolates:

Ten concentrations of sodium chloride $(1,3,5,7,10,12,14,16,18$, and 20)\% with nutrient agar were prepared and inoculated by Sawa Lake isolates, then incubated for $24 \mathrm{~h}$ at $30^{\circ} \mathrm{C}$. 
Screening of osmophilic Bacillus isolates:

Nutrient agar with $(1,3,5,7,10,12,14,16,18$, and 20$) \%$ of sucrose were prepared and inoculated by Sawa Lake isolates, then incubated for $24 \mathrm{~h}$ at $30^{\circ} \mathrm{C}$.

\section{Fermentation media:}

Fermentation media with the following composition $(\mathrm{gm} / \mathrm{l})$ was used for levansucrase production and biomass calculated: $\mathrm{K}_{2} \mathrm{HPO}_{4}(1.5), \mathrm{KH}_{2} \mathrm{PO}_{4}(1.5)$, $\mathrm{MgSO}_{4} .7 \mathrm{H}_{2} \mathrm{O}(0.2), \mathrm{NH}_{4} \mathrm{Cl}(0.5)$, yeast extract (2), media were supplemented with 50ml of $\mathrm{CaCl}_{2}(5 \mathrm{mM})$ and $(10,20,30,40,50,60,70,80,90$ and 100$) \mathrm{gm}$ of $\mathrm{NaCl}$, (Sucrose+Sodium chloride) and sucrose, respectively, then the media were completed with distilled water to one liter, $\mathrm{pH}$ was adjusted to 7.0 before autoclaving.

\section{Levansucrase production:
Screening on solid media:}

In the present work Bacillus isolates were activated in Brain Heart Infusion broth (B.H.I.), 0.1 $\mathrm{ml}$ of culture was streaked on tryptone sucrose agar medium, composed of (gm/l): sucrose 20 , yeast extract 4 , tryptone $17, \mathrm{~K}_{2} \mathrm{HPO}_{4} 2.5$, agar 2, $\mathrm{pH} 7.0$, then plates were incubated at $30^{\circ} \mathrm{C}$ for $48 \mathrm{~h}$.

\section{Levansucrase Activity Assay:}

Cells were harvested by refrigerated centrifuge at 5000rpm for 10min after inoculated fermentation media with Bacillus isolate and incubation for $48 \mathrm{~h}$ at $30^{\circ} \mathrm{C}$, then the supernatant was used as enzyme source. Levansucrase activity was assayed by measuring the reducing sugar liberated during sucrose hydrolysis. The reaction mixture $[250 \mu 1$ of enzyme extract and $250 \mu 1$ of $1 \mathrm{M}$ sucrose in acetate buffer $(50 \mathrm{mM}, \mathrm{pH} 5.0)]$ was incubated at $30^{\circ} \mathrm{C}$ for $30 \mathrm{~min}$. Reducing sugar released was determined and measured absorbance at $575 \mathrm{~nm}$ according to the method of (Miller, 1959). One unit of levansucrase activity was expressed as the amount of enzyme required to liberate $1 \mu \mathrm{mol}$ of reducing sugar from sucrose in $1 \mathrm{~min}$ under experimental conditions.

\section{RESULTS AND DISCUSSION}

\section{Collection of samples:}

Sawa Lake water (TDS 20800ppm) was heat-treated to kill all vegetative cells, then cultured on nutrient agar to allow germination and growth of heatresistant spores. Morphological diagnoses of pure isolates were characteristics and determined by microscopy (Gram and spore staining). Four spores-former isolates (Saw 1, Saw 2, Saw 3 and Saw 4) were isolated after incubated for $24 \mathrm{~h}$ at $30^{\circ} \mathrm{C}$.

\section{The ability of Bacillus isolates growth on various concentrations of $\mathrm{NaCl}$ :}

Results showed that Bacillus isolates (Saw 2 and Saw 3) were responded to various concentrations of $\mathrm{NaCl}$ and grown up to $14 \%$ of $\mathrm{NaCl}$ concentrations with nutrient agar, whereas isolates ( $\mathrm{Saw} 1$ and Saw 4) tolerant to $\mathrm{NaCl}$ concentrations reaching to $12 \%$, after incubating for $24 \mathrm{~h}$ at $30^{\circ} \mathrm{C}$ (Table 1 ).

Microorganisms have to equilibrium the vital osmotic gradient across their cytoplasmic membrane indirectly by influencing the osmotic capability of the cytoplasm to coordinate the motion of water in or out of the cell. They accumulate water-attracting ions and organic osmolytes, when they encounter hyperosmotic conditions to prevent cellular dehydration (Bremer and Kramer, 2000) and they quickly remove these compounds through the transient opening of mechanosensitive channels to avert cell rupture (Haswell et al., 2011).

Table 1: Growth ofBacillusisolates in various concentrations of $\mathrm{NaCl}$

\begin{tabular}{clccc}
\hline Conc. of $\mathrm{NaCl} \%$ & Saw 1 & Saw 2 & Saw 3 & \\
\hline 1 & $\mathrm{R}$ & $\mathrm{R}$ & $\mathrm{R}$ & $\mathrm{R}$ \\
$\mathrm{R}$ & $\mathrm{R}$ & $\mathrm{R}$ & $\mathrm{R}$ & $\mathrm{R}$ \\
5 & $\mathrm{R}$ & $\mathrm{R}$ & $\mathrm{R}$ & $\mathrm{R}$ \\
7 & $\mathrm{R}$ & $\mathrm{R}$ & $\mathrm{R}$ & $\mathrm{M}$ \\
10 & $\mathrm{R}$ & $\mathrm{R}$ & $\mathrm{M}$ & \\
12 & $\mathrm{M}$ & $\mathrm{R}$ & $\mathrm{M}$ & $\mathrm{S}$ \\
14 & $\mathrm{~S}$ & $\mathrm{~S}$ & $\mathrm{~S}$ & $\mathrm{~S}$ \\
16 & $\mathrm{~S}$ & $\mathrm{~S}$ & $\mathrm{~S}$ \\
18 & $\mathrm{~S}$ & $\mathrm{~S}$ & $\mathrm{~S}$ & \\
20 & $\mathrm{~S}$ & $\mathrm{~S}$ & $\mathrm{~S}$ & \\
\hline
\end{tabular}

The effect of different concentrations of sucrose on Bacillus isolates growth:

Results indicated that Bacillus isolates (Saw 1, Saw 2, Saw 3 and Saw 4) were resisted to different concentrations of sucrose reaching to $200 \mathrm{gm} / 1$ with nutrient agar after incubating for $24 \mathrm{~h}$ at $30^{\circ} \mathrm{C}$ (Table 2).

Table 2: Effect of various concentrations of sucrose onBacillusisolates

\begin{tabular}{cccc}
\hline Conc. of sucrose $\%$ & Saw 1 & Saw 2 & Saw 3 \\
\hline 1 & $\mathrm{R}$ & $\mathrm{R}$ & $\mathrm{R}$ \\
3 & $\mathrm{R}$ & $\mathrm{R}$ & $\mathrm{R}$ \\
5 & $\mathrm{R}$ & $\mathrm{R}$ & $\mathrm{R}$ \\
7 & $\mathrm{R}$ & $\mathrm{R}$ & $\mathrm{R}$ \\
10 & $\mathrm{R}$ & $\mathrm{R}$ & $\mathrm{R}$ \\
12 & $\mathrm{R}$ & $\mathrm{R}$ & $\mathrm{R}$ \\
14 & $\mathrm{R}$ & $\mathrm{R}$ & $\mathrm{R}$ \\
16 & $\mathrm{R}$ & $\mathrm{R}$ & $\mathrm{R}$ \\
18 & $\mathrm{R}$ & $\mathrm{R}$ & $\mathrm{R}$ \\
20 & $\mathrm{R}$ & $\mathrm{R}$ & $\mathrm{R}$ \\
$\mathrm{R}$ & $\mathrm{R}$ & $\mathrm{R}$ \\
\hline
\end{tabular}

\footnotetext{
R: Resistant
}

Many osmophile microorganisms belong to yeast and bacteria were adapted to high osmotic pressure environments, such as high sugar concentrations. Osmophiles are similar to salt-loving microorganisms because a critical aspect of both types of environment is their low water activity ( $\mathrm{a}_{\mathrm{w}}$ ). High sugar concentrations were the growth-limiting factors for many microorganisms, however, osmophiles protect themselves against this high osmotic pressure by the synthesis of osmoprotectants, such as alcohols and amino acids (Beuchat, 1981). 
Citation: Adnan H. Abbas, Eman H. Abed, Seham M. Mohammed, 2018. Efficiency of Moderately HalophilicBacillusspp. Isolated From Hypersaline Environments In Producing Levansucrase. Australian Journal of Basic and Applied Sciences., 12(1): 28-31.

It is likely that the synthesis and accumulation of glycerol, the poly of choice for osmotic adjustment in xerophilic fungi in high salt (low water-activity) (Lima Alves et al., 2015), could facilitate fungal colonization in very salty environment by alleviating against, osmotic stress, low water-activity and ionic strength.

\section{Measurement of cell biomass concentration:}

Cell biomass of Bacillus isolate (Saw 2) was determined after incubating at $30^{\circ} \mathrm{C}$ for $48 \mathrm{~h}$ in media with $(\mathrm{NaCl}),(\mathrm{NaCl}+\mathrm{Sucrose})$ and (Sucrose), concentrations up to $10 \%$, respectively, and quantified as a milligram of the dry weight of (viable and dead) cells per $1 \mathrm{ml}$ of sample. The cells in a sample can be separated from the broth and thoroughly dried before weighing.

Results showed that cell biomass of (Saw 2) were enhanced under high concentrated of $(\mathrm{NaCl}),(\mathrm{NaCl}+\mathrm{Sucrose})$ and (Sucrose), at (1-10)gm/100ml, respectively, with more affected and increasing in value of cell biomass during add mixture of ( $\mathrm{NaCl}+\mathrm{Sucrose})$ to fermentation media (Figure 1).

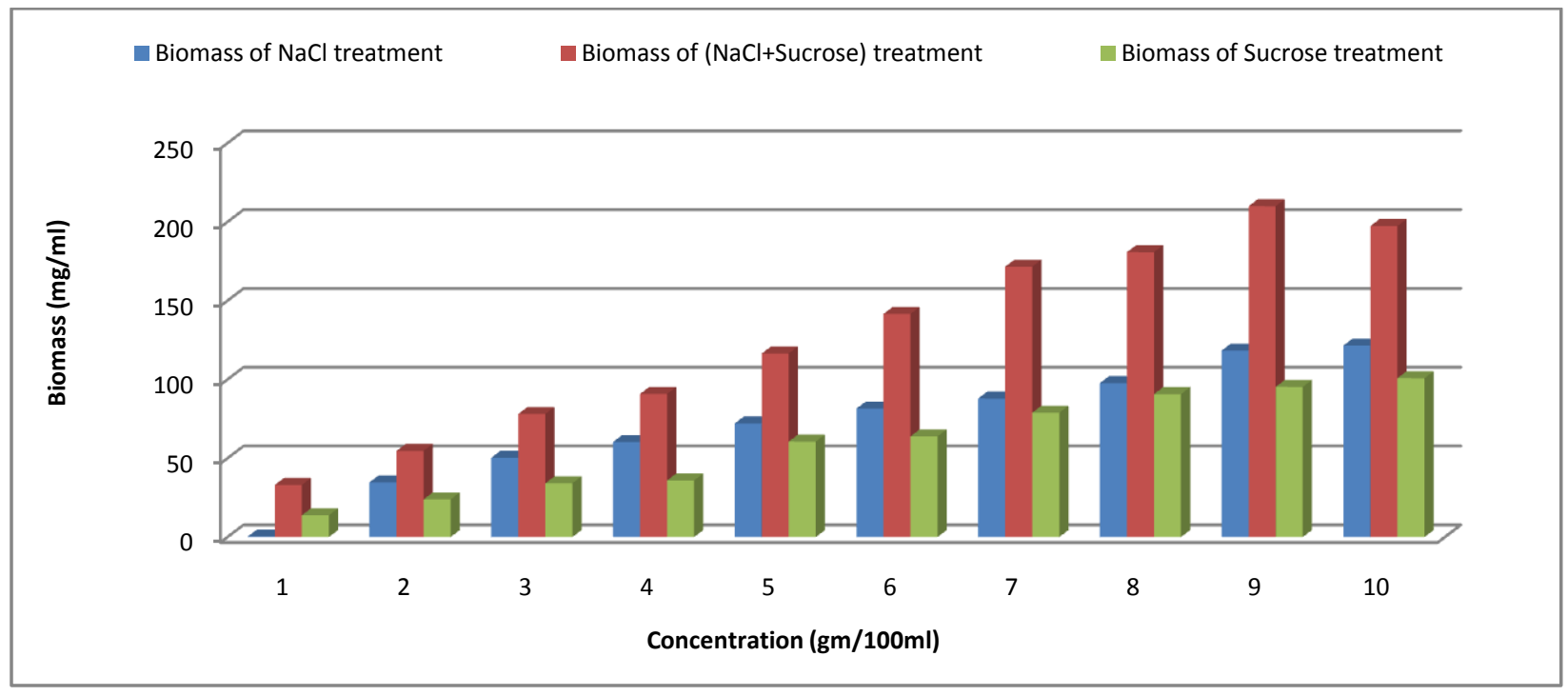

Fig. 1: Effect of (1-10)gm/100ml from $\mathrm{NaCl},\left(\mathrm{NaCl}\right.$ and Sucrose), and Sucrose on cell biomass of (Saw 2) isolate after incubating at $30^{\circ} \mathrm{C}$ for $48 \mathrm{~h}$.

This evidence exhibited that Bacillus isolate(Saw 2) can grow within a wide rangeof solute concentrations,ashighosmoticpressure environments. Generally microorganisms capable of growing at water activity $\left(a_{w}\right)$ value 0.85 or less. Well known, mechanisms employed by these organisms to overcome increased osmotic pressure are the intracellular solute accumulation and altered membrane permeability (Pettersson and Leong, 2011).

\section{Qualitative assay for levansucrase:}

Appearance of mucous consistency of bacterial colonies on the sucrose agar medium by using sucrose as carbon source after incubating at $30^{\circ} \mathrm{C}$ for $48 \mathrm{~h}$, was the indicator of secreted inducible extracellular levansucrase (Figure 2), which catalyze the exchange of the fructosyl unit of sucrose to various acceptors including sucrose, water and fructan polymer (Perez-Oseguera et al., 1996).

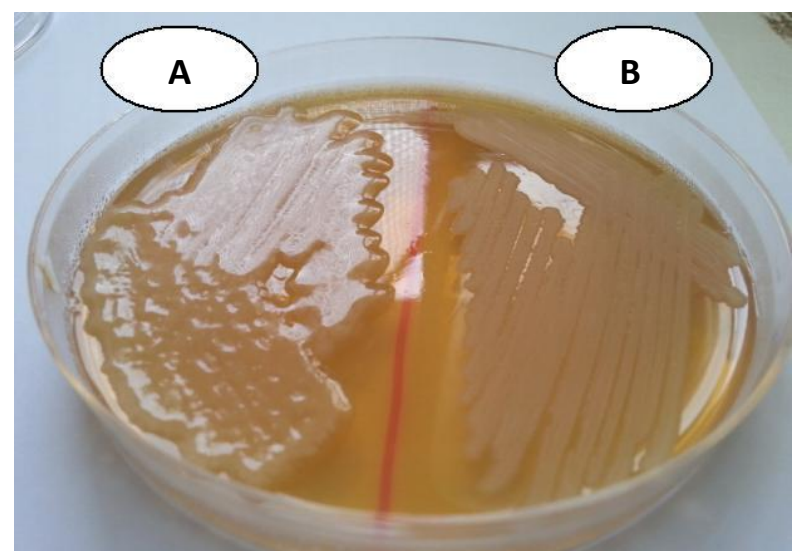

Fig. 2: Exopolysaccharide production (Levansucrase production) A- Positive B- Negative

\section{Quantitative assay for levansucrase:}

In the present work, it was trained to analyze the ability of moderately halophilic isolate (Saw 2) to produce levansucrase by utilizing sucrose as a sole carbon source. The levansucrase activity in cell free supernatant was estimated after incubated at $30^{\circ} \mathrm{C}$ for $48 \mathrm{~h}$ and showed that (Saw 2) isolate produced levansucrase at concentrations $(1-10) \mathrm{gm} / 100 \mathrm{ml}$ of $(\mathrm{NaCl}+$ Sucrose), with activity, $(462.08,463.33,460.83,460.83,455.41,453.75,452.97,454.58,454.16$ and 452.07$) \mathrm{U} / \mathrm{ml}$ and descending quantity in enzyme activity $(439.37,450.41,431.66,422.29,381.04,361.87,312.29,315,276.25$ and 251.87$)$ U/ml when added sucrose concentration to fermentation media more than $4 \mathrm{gm} / 100 \mathrm{ml}$ (Figure 3 ). 


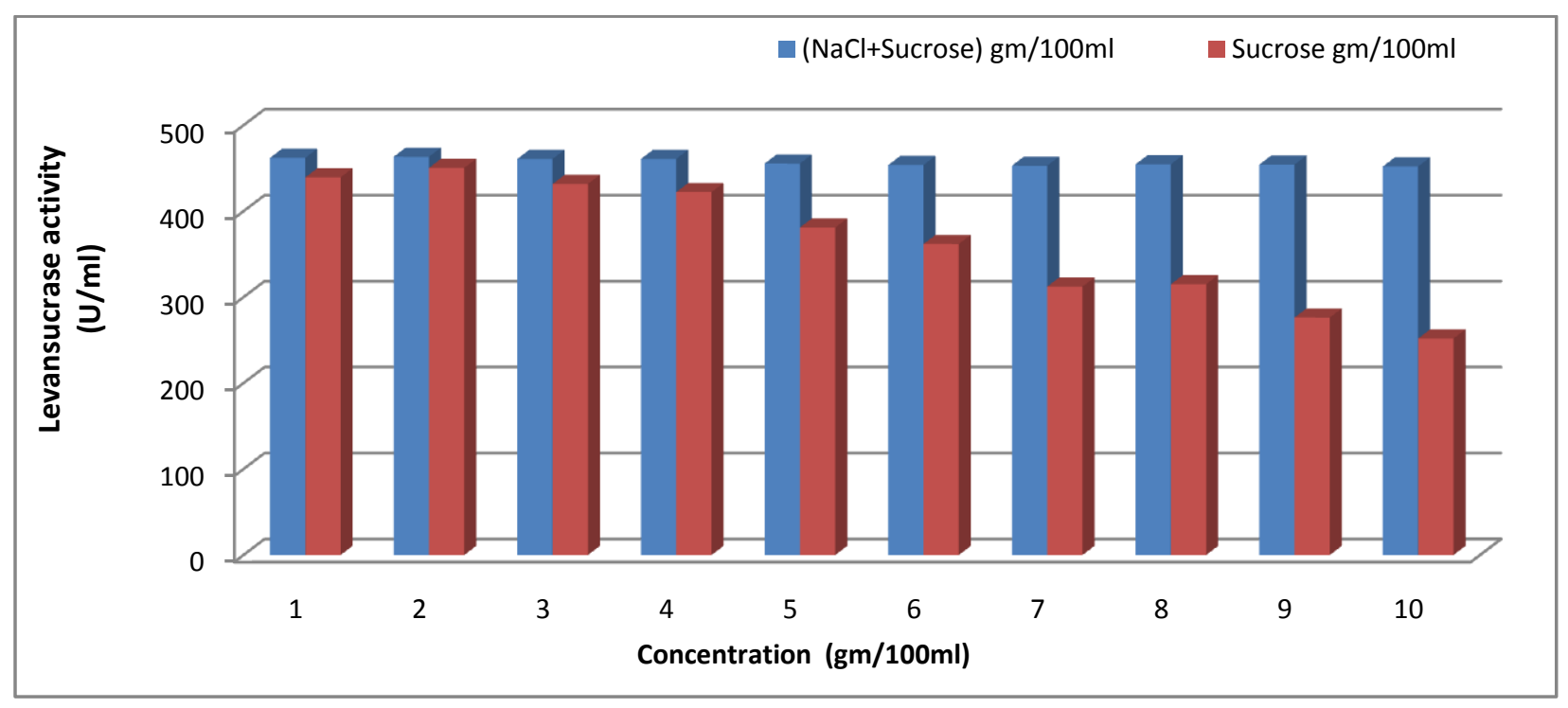

Fig 3: Levansucrase activity (U/ml) producing by (Saw 2) isolate inoculated media with $(\mathrm{NaCl}+\mathrm{Sucrose})$ and (Sucrose) $(1-10) \mathrm{gm} / 100 \mathrm{ml}$ after incubating at $30^{\circ} \mathrm{C}$ for $48 \mathrm{~h}$.

\section{CONCLUSIONS}

This study showed that moderately halophilic Bacillus isolates from hypersaline environments able to grow and produced levan via liberated levansucrase under salt and sucrose conditions, reached to $100 \mathrm{gm} / \mathrm{l}$, after incubating at $30^{\circ} \mathrm{C}$ for $48 \mathrm{~h}$. The availability of moderately halophilic bacteria was in producing important material, which used in several applications ranging from food and feed (prebiotics, stabilizer, fat substitute), cosmetics (whitener, moisturizer), to pharmaceuticals (anti-oxidant, anti-inflammatory, anti-cancer activities) industries.

\section{REFERENCES} 347.

Ahmad, N.H., S. Mustafa and Y.B. Che Man, 2015. Microbial polysaccharides and their modification approaches: a review. Int Journal Food Prop, 18: 332-

Belghith, K.S., I. Dahech, I. Belghith and H. Mejdoub, 2012. Microbial production of synthesis of fructooligosaccharides and levan. International Journal of Biological Macromolecule, 50: 451-458.

Beuchat, L.R., 1981. "Efficacy of agar media for enumerating two Saccharomyces species in sucrose syrups". Mycopathologia Springer Netherlands, 76(3):13-17.

Bremer, E., and R. Kramer, 2000. Coping with osmotic challenges: Osmoregulation through accumulation and release of compatible solutes. In: G. Storz R.Hengge-Acronis. Bacterial Stress Responses, pp: 79-97.

Dahech, I., K.S. Belghith, H. Belghith and H. Mejdoub, 2012. Partial purification of Bacillus licheniformis levansucrase producing levan with antitumor activity. International Journal of Biological Macromolecules, 51: 329-335.

Dahech, I., B. Harrabi, K. Hamden, A. Feki, K.S. Belghith, H. Belghith and H. Mejdoub, 2013. Antioxidant effect of nondigestible levan and its impact on cardiovascular disease and atherosclerosis. International Journal of Biological Macromolecules, 58: 281-286.

Esawy, M.A., H. Amer, A.M. Gamal-Eldeen, H.A. El Enshasy, W.A. Helmy, M.A.M. Abo-Zeid, R. Malek, E.F. Ahmed and G.E.A. Awad, 2013. Scaling up, characterization of levan and its inhibitory role in carcinogenesis initiation stage. Carbohydrate Polymer, 95: 578-587.

Haswell, E.S., R. Phillips and D.C. Rees, 2011. Mechanosensitive channels: what can they do and how do they do it? Structure, 19: 1356-1369.

Karan, R., S. Kumar, R. Sinha and S.K. Khare, 2012. Halophilic microorganisms as sources of novel enzymes. In Satyanarayana, T. (ed.) Microorganisms in Sustainable Agriculture and Biotechnology: Springer.

Kushner, D.J., and M. Kamekura, 1988. Physiology of halophilic eubacteria. In: Halophilic bacteria, Vol. 1 (Rodriguez-Valera, F., Ed.), pp: 109-138.

Lanyi, J.K., 1974. Salt-dependent properties of proteins from extremely halophilic bacteria. Bacteriology Rev, 38: 272-290.

Lima Alves, D.E., F. Stevenson, A. Baxter, E. Gillion, J.L. Hejazi and F. Hayes, 2015. Concomitant osmotic and chaotropicity-induced stresses in Aspergillus wentii: compatible solutes determine the biotic window. Curr Genet, 61: 457-477. 938.

Manzoni, S., J.P. Schimel and A. Porporato, 2012. Responses of soil microbial communities to water-stress: results from a meta-analysis. Ecology, 93: 930-

Miller, G.L., 1959. Use of dinitrosalicylic acid reagent for determination of reducing sugar. Analytical Chem, 31: 426-428.

Moyano, F.E., S. Manzoni and C. Chenu, 2013. Responses of soil heterotrophic respiration to moisture availability: an exploration of processes and models.Soil Biology, Biochemistry, 59: 72-85.

Perez-Oseguera, M.A., L. Guereca and A. Lopez-Munguia, 1996. Properties of levansucrase from Bacillus circulans. Apple Microbiology Biotechnology,45: 465-471.

Pettersson, O.V., and S.L. Leong, 2011. Fungal xerophiles (Osmophiles). In ELS (Encyclopedia of Life Sciences). John Wiley \& Sons, Ltd., Chichester, UK.

Ruhmann, B., J. Schmid and V. Sieber, 2015. High throughput exopolysaccharide screening platform: from strain cultivation to monosaccharide composition and carbohydrate fingerprinting in one day. Carbohydrate Polym, 122: 212-220.

Sogotcu, E., Z. Emerence, M. Arikan, A. Cakiris, N. Abaci, E.T. Oner, D. Ustek and Y. Arga, 2012. Draft genome sequence of Halomonas smymensisAAD6T. Journal of Bacteriology, pp: 5690-5691.

Srikanth R., C.H. Reddy, G. Siddartha, M.J. Ramaiah and K.B. Uppuluri, 2015. Review on production, characterization and applications of microbial levan. Carbohydrate Polym, 120: 102-114.

Stecchini, M., and L.R. Beuchat, 1985. Effects of sugars in growth media, diluents and enumeration media on survival and recovery of Saccharomycescerevisiae. Food Microbiology, 2: 85-95. 